\title{
EVALUASI TINGGI EMBANKMENT JALAN PADA TANAH LUNAK DIPERKUAT GEOTEXTILE DAN FONDASI CERUCUK
}

\author{
Suyuti $^{1)}$, Muhammad Rizal ${ }^{2}$ \\ Program Studi Teknik Sipil Universitas Khairun \\ email: suyuti@unkhair.ac.id ${ }^{1)}$, muhrizal@unkhair.ac.id $^{2)}$
}

DOI: http://dx.doi.org/10.29103/tj.v10i2.320

(Received: June 2020 / Revised: August 2020 / Accepted: August 2020)

\begin{abstract}
Abstrak
Kalimantan memiliki daratan rendah tanah lunak mencapai kedalaman $25 \mathrm{~m}$. Tanah lunak memiliki kapasitas dukung rendah dan deformasi besar untuk menopang bebanbeban. Infrastruktur seperti embankment untuk konstruksi jalan di atas tanah dasar lunak, biasanya direncanakan dengan suatu tinggi rencana, meskipun embankment untuk konstruksi jalan sering runtuh akibat lemahnya kekakukan tanah dasar tersebut. Ada beberapa pedoman teknik telah dipublikasikan bagaimana cara membangun embankment di atas tanah lunak, tetapi pedoman tersebut hanya menunjukkan prosedur kerja konstruksi, di mana ujung pangkal fondasi cerucuk seperti kayu atau bambu adalah diikat dengan cara konvensional. Konstruksi embankment harus memenuhi untuk kriteria stabilitas dan penurunan. Penelitian ini untuk pemenuhan persyaratan stabilitas seperti faktor keamanan embankment dihubungkan dengan kapasitas dukung tanah lunak dengan perkuatan untuk mengevaluasi tinggi embankment disediakan dengan beberapa formula empiris berdasarkan aturan geoteknik. Hasil simulasi perhitungan diperoleh tinggi embankment kritis $H_{c r}$ sebesar $1,06 \mathrm{~m}$ untuk kohesi tanah $c_{u}$ sebesar $11,5 \mathrm{kN} / \mathrm{m}^{2}$ dan $H_{c r}$ sebesar 1,70 1,73 m untuk kohesi $c_{u}$ sebesar $17,5 \mathrm{kN} / \mathrm{m}^{2}$ dengan fondasi cerucuk berjarak $s$ sebesar $10 D$. Variasi susunan cerucuk berjarak s of 3,3D memberikan nilai signifikan kapasitas dukung batas dan konstruksi embankment lebih tinggi, hal ini adalah tidak memberikan nilai signifikan oleh indeks plastisitas tanah.
\end{abstract}

Kata kunci: tinggi embankment, tanah lunak, geotextile, fondasi cerucuk

\begin{abstract}
Kalimantan island has lowlands of soft soil in down depth $25 \mathrm{~m}$. The soft soil has low bearing capacity and large deformation to support loads. Infrastructure such as embankment for road construction on the soft soil, it is usually planned by a height target. However, the embankment for road construction is often collapsed due to weak stiffness of soil subgrade. Therefore, the local government has been used geotextile and installed timber pile for reinforcing the soft soil. There are several technique guidelines published how to build embankment on soft soil, but that guidelines are only shown the prosedure for working the construction. The soft soil installed timber pile perior to lay geotextile and construct an embankment. Where the top of cerucuk foundation such as timber or bamboo is tied by conventional system. The embankment construction have to satisfy for stability and settlement criteria. In this research, the stability requirement such as factor of safety of embankment is conducted by bearing capacity of soft soil with reinforcement to evaluated a critical height of its embankment, which is provided by several empirical formula based on rule of geotechnics. The simulation results were obtained critical height of embankmentt $H_{c r}$ of $1,06 \mathrm{~m}$ for soil cohesion $c_{u}$ of $11,5 \mathrm{kN} / \mathrm{m}^{2}$ and $H_{c r}$ of 1,70 1,73
\end{abstract}

Evaluasi Tinggi Embankment Jalan Pada Tanah Lunak Diperkuat Geotextile dan Fondasi Cerucuk - Suyuti, Muhammad Rizal 
m for cohesion $c_{u}$ of $17,5 \mathrm{kN} / \mathrm{m}^{2}$ with cerucuk foundation on spacing $s$ of $10 D$. Variation of rearrange of cerucuk spacing $s$ of 3,3D are given significant values of ultimate bearing capacities, and more heighly of embankment construction, it is not given a significant value by plasticity index of soil.

Keywords: Embankment height, soft soil, geotextile, cerucuk foundation

\section{Latar Belakang}

Kapasitas dukung batas tanah dasar ditentukan oleh parameter seperti: kohesi $(c)$, sudut gesek dalam tanah $(\varphi)$, dan berat volume tanah $(\gamma)$. Tanah dasar lunak atau tanah gambut memiliki parameter tanah tersebut adalah rendah, sehingga kekakuan tanah juga menjadi kecil dan memiliki deformasi besar. Terdapat banyak area daratan rendah yang tertutup tanah lunak atau tanah gambut di Indonesia, di mana salah satunya, area daratan tertutup tanah lunak atau gambut seperti di bagian selatan pulau Kalimantan. Menurut (Yudiawati and Marzuki, 2008) bahwa di Banjarmasin Kalimantan Selatan terdapat lapisan tanah lunak mencapai kedalaman sekitar $25 \mathrm{~m}$. Hal ini bahwa pekerjaan konstruksi jalan di atas area tersebut di atas akan dapat mengalami permasalahan keruntuhan.

Nenek moyang orang lokal Indonesia telah menerapkan konsep pondasi perkuatan mekanis traditional (cerucuk) seperti kayu atau bambu untuk meningkatkan nilai kekakuan tanah dasar lunak. Begitupun, instansi teknik Departmen Pekerjaan Umum telah menerbitkan beberapa pedoman teknis prosedur pelaksanaan konstruksi embankment untuk jalan di atas tanah lunak atau tanah gambut, sayangnya, prosedur pelaksanaan dan cara perhitungan konstruksi embankment jalan ini adalah masih sulit untuk diterapkan menentukan dan mengevaluasi tinggi target embankment jalan di atas tanah lunak, karena lokasi pekerjaan konstruksi jalan akan berbeda dan parameter tanah dasar akan bervariasi. Menurut (Yudiawati and Marzuki, 2008) bahwa pembangunan timbunan konstruksi pelebaran jalan Simpang Serapat KM 17 Lingkar Utara, Kalimantan Tengah, di mana lapisan tanah dasar telah diperoleh berjenis tanah rawa atau tanah lunak. Mereka melaporkan bahwa pembangunan timbunan jalan telah menggunakan perkuatan geotextile and kayu galam $(D) 10 \mathrm{~cm}$, jarak antara tiang $(s) 1.0 \mathrm{~m}$, panjang $(L) 4 \mathrm{~m}$, di mana bahan perkuatan geotextile diletakkan di atas permukaan tanah, dan diperoleh tinggi embankment kritis di lapangan.

Menurut (Suyuti et al., 2018) kapasitas dukung batas tanah dasar sangat lunak dengan matras di mana tanah distabilisasi semen $10 \%$ yang diperkuat cerucuk, hasil penelitian menunjukkan bahwa dengan pemasangan tiang-tiang bambu di dalam tanah lunak mampu meningkatkan kapasitas dukung tanah dasar tersebut hingga mencapai $q_{u r}$ sebesar $49 \mathrm{kN} / \mathrm{m}^{2}$ atau setara dengan CBR 4,9\%.

Penelitian ini mengusulkan metode evaluasi tinggi kritis embankment di atas tanah lunak diperkuat dengan geotextile dan fondasi cerucuk di mana usulan metode ini akan menggunakan persamaan-persamaan matematis berdasarkan konsep dasar geoteknik, seperti teori klasik kapasitas dukung batas tanah $\left(q_{u}\right)$ (Terzaghi and Peck, 2009).

\section{Metode Penelitian}

Metode penelitian adalah menggunakan studi literatur, data hasil penelitian sebelumnya dan simulasi-simulasi perhitungan tinggi kritis embankment. 


\subsection{Teori dasar}

Menurut (Suyuti et al., 2018) hasil penyelidikannya bahwa pemasangan fondasi cerucuk pada tanah lunak di bawah struktur sloef bangunan adalah telah mampu meningkatkan kapasitas dukung batas tanah $\left(q_{u r}\right)$ dapat menjadi minimal 2,5 kali lipat (di mana: diameter $(D) 12 \mathrm{~cm}$, jarak antara tiang $(s) 40 \mathrm{~cm}$, panjang (L) 6m). Berdasarkan (Pekerjaan Umum, 1999) telah mempublikasikan pedoman teknis prosedur pelaksanaan konstruksi embankment jalan di atas tanah lunak yang diperkuat cerucuk dengan prosedur seperti; 1) pemancangan fondasi cerucuk seperti kayu atau bambu, 2) pemasangan kayu gapit (arah melintang dan memanjang jalan), 3) meletakkan lembar geotextile, dan 4) konstruksi embankment. Semnetara itu (Koerner et al., 1987) telah mempelajari bahwa embankment dibangun di atas pondasi tanah lunak yang diperkuat geosynthetic, hal ini dapat diadopsi untuk mengevaluasi tinggi desain dengan menerapkan salah satu konsep model kerutuhan kapasitas dukung tanah dasar lunak sebagaimana ditunjukkan seperti Gambar 1.

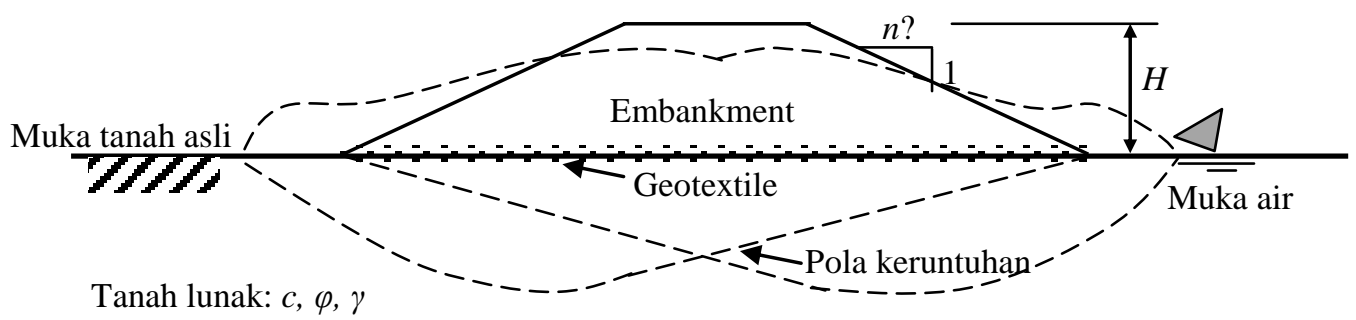

Gambar 1 Pola keruntuhan kapasitas dukung tanah dasar lunak diperkuat geotextile di mana $n$ gradien rencana embankment, $H$ tinggi embankment.

Gambar 1 menunjukkan bahwa persamaan konvensional geoteknik untuk tekanan ijin embankment pada permukaan tanah dasar diperkuat geotextile $\left(q_{\text {arl }}\right)$ dapat ditulis:

$$
q_{a r 1}=\frac{q_{n r 1}}{F k}
$$

di mana:

$$
\begin{aligned}
q_{n r 1}= & \text { kapasitas dukung batas fondasi tanah dasar lunak yang diperkuat } \\
& \text { geotextile, } \\
F k= & \text { faktor keamanan. }
\end{aligned}
$$

Dalam pedoman teknis bahwa meningkatkan kekakuan dan mereduksi penurunan tanah dasar akibat pembebanan, maka fondasi tanah dasar lunak dipancangkan cerucuk sebagai pondasi adalah telah dipublikasikan (Pekerjaan Umum, 2002). Sementara itu (Pekerjaan Umum, 2005) telah mempublikasikan pedoman teknis uji coba lapangan konstruksi pondasi tanah lunak dengan sistem matras dan pemasangan cerucuk, di mana konstruksi matras adalah tanah lunak quary galian lokal distabilisasi. Selanjutnya, pengujian kapasitas dukungnya matras dievaluasi dengan menggunakan metode CBR lapangan. Lihat Gambar 2.

Berdasarkan (Adriani and Herliyana, 2012) melaporkan hasil kasus studi penelitiannya bahwa tinggi embankment kritis sebesar $H_{c r} 1,40 \mathrm{~m}$ dan tinggi embankment rencana $\left(H_{\text {renc }}\right)$ sebesar $1,50 \mathrm{~m}$, di mana konsep perencanaan stabilitas konstruksi jalan bahwa tekanan pembebanan embankment $\left(p_{e b}\right)$ adalah 
harus kurang dari kapasitas dukung bersih tanah dasar lunak dengan perkuatan geotextile dan kayu galam $\left(q_{n r 2}\right)$ dapat ditulis:

$$
p_{e b}<q_{n r 2}
$$

Persamaan (2) menunjukkan bahwa konstruksi jalan di atas tanah lunak dengan perkuatan dapat memberikan faktor keamanan $(F k)>1.0$.

Menurut (Suyuti et al., 2020b) hasil studi pemodelan skala penuh bahwa kapasitas dukung fondasi matras-tanah distabilisasi semen $10 \%$ di atas tanah sangat lunak yang diperkuat geo-bambu dan dipancang tiang-tiang bambu pola bujur sangkar diameter $D 8.07 \mathrm{~cm}$, jarak tiang s $3 D$, panjang $L 100 \mathrm{~cm}$, penentuan kapasitas dukung fondasi matras dengan metode CBR lapangan dilaporkan sebesar $4,9 \%$.

\subsection{Metode Perhitungan}

Penelitian ini adalah difokuskan pada metode evaluasi tinggi kritis konstruksi embankment jalan di atas tanah dasar lunak diperkuat geotextile dan fondasi cerucuk. Metode perhitungan adalah diusulkan sebagai berikut:

1. Studi kasus: Sebagai studi kasus adalah konstruksi embankment jalan di atas tanah lunak yang diperkuat geotextile dan dipasang cerucuk. Tanah lunak seragam perlu diasumsikan bahwa kohesi tak terdrainase $\left(c_{u}\right)$, sudut gesek dalam tanah $\left(\varphi_{s}\right)$ dan berat volume tanah $\left(\gamma_{s}\right)$ (Adriani dan Herliyana, 2012). Bahan fabrikasi geotextile diasumsikan memiliki kuat tarik $\left(T_{g t}\right)$.

2. Pedoman teknis: Pedoman teknis tentang prosedur pelaksanaan konstruksi embankment jalan di atas tanah lunak atau tanah gambut dengan perkuatan konvensional geotextile didukung fondasi cerucuk.

3. Studi literatur: Untuk menyajikan simulasi dan evaluasi desain embankment berdasarkan studi kasus di atas, maka dengan kesesuaian pertimbangan desain embankment adalah diadopsi formula empiris klasik (Terzaghi and Peck, 2009).

4. Simulasi dan evaluasi desain: Tahapan simulasi perhitungan akan disajikan menggunakan formula empiris, yang memvariasikan beberapa nilai kohesi tanah dasar, dan jarak perkuatan cerucuk kayu.

\subsection{Penentuan kapasitas dukung batas}

Fondasi tanah dasar lunak dengan sistem perkuatan konvensional seperti tanah dasar, geotextile, dan cerucuk untuk embankment jalan seperti Gambar 2.

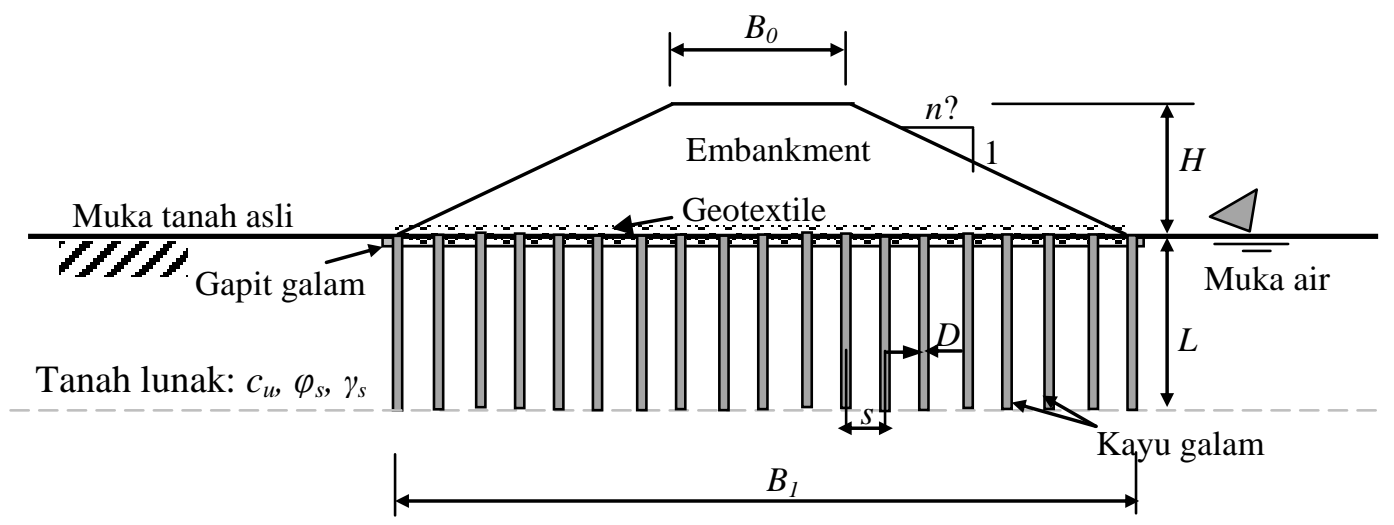

Gambar 2 Konstruksi embankment jalan dengan sistem perkuatan konvensional

Evaluasi Tinggi Embankment Jalan Pada Tanah Lunak Diperkuat Geotextile dan Fondasi Cerucuk - Suyuti, Muhammad Rizal 
Gambar 2 menunjukkan bahwa kapasitas dukung bersih pondasi tanah dasar dengan cerucuk $q_{n r}$ dapat ditulis:

$$
q_{n r}=q_{u}+q_{g t}+\left(q_{c g}-\gamma_{s p} L\right)
$$

Kapasitas dukung batas tanah dasar $\left(q_{u}\right)$ untuk embankmen jalan dengan lebar telapak memanjang $B_{1}$ seperrti pada Gambar 2 adalah dapat didefenisikan sebagai (Braja, 1979).

$$
q_{u}=c_{u} N_{c}+\gamma_{s} D_{f} N_{q}+\frac{1}{2} B \gamma_{s} N_{\gamma}
$$

di mana $N_{q}, N_{c}, N_{\gamma}$ adalah faktor-faktor kapasitas dukung tanah adalah dapat ditentukan (Das, 1979)

$$
\begin{aligned}
& N_{q}=\exp \left(\pi \tan \phi_{s}\right) \tan ^{2}\left(45+\frac{\phi_{s}}{2}\right) \\
& N_{c}=\left(N_{q}-1\right) \cot \phi_{s} \\
& N_{\gamma}=2\left(N_{q}+1\right) \tan \phi_{s}
\end{aligned}
$$

$c_{u}=$ kohesi tak terdrainase tanah lunak $\left(\mathrm{kN} / \mathrm{m}^{2}\right) ; \gamma_{s}=$ berat volume tanah $\left(\mathrm{kN} / \mathrm{m}^{3}\right)$; $B_{1}=$ lebar fondasi cerucuk (m); dan $D_{f}=$ kedalaman pondasi telapak (m).

Untuk tanah dasar lunak lempung dengan $\left(\varphi_{s} \approx 0^{\circ}\right)$. Dari persamaan (4) dan (5). Kapasitas dukung batas tanah dasar lempung bawah tiang-tiang $q_{u}\left(\mathrm{kN} / \mathrm{m}^{2}\right)$ adalah

$$
q_{u}=c_{u} N_{c}
$$

Perkuatan dengan geotextile diletakkan di atas susunan balok gapit yang telah diperkuat oleh cerucuk (lihat Gambar 3). Idealisasi perhitungan kapasitas dukung tanah dasar diperkuat geotextile dan cerucuk adalah ditunjukkan pada Gambar 4 menunjukkan bahwa kapasitas dukung batas tanah dasar yang diperkuat geotextile $\left(q_{g t}\right)$ dapat ditentukan (Yamanouchi and Gotoh, 1979):

$$
q_{g t}=\frac{2 T_{g t} \sin \phi_{r}}{B_{1}}
$$

di mana kapasitas dukung tarik geotextile yang bekerja adalah diasumsikan terjadi deformasi vertikal (Pekerjaan Umum, 2002).

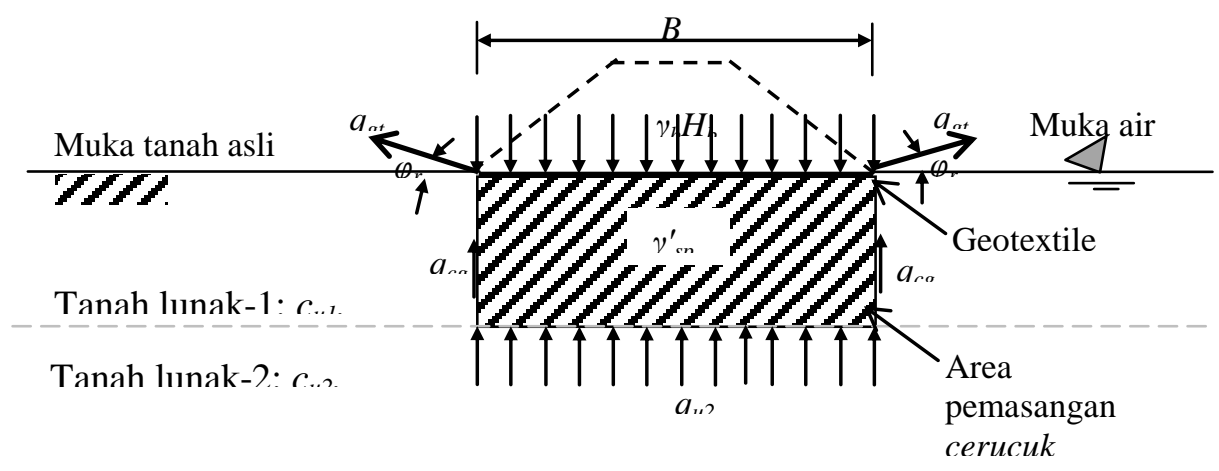

Gambar 3 Idealisasi perhitungan kapasitas dukung tanah dasar dengan fondasi cerucuk 
Lebar bawah embankment $B_{1}$ adalah diperhitungan dengan persamaan:

$$
B_{1}=B_{0}+2 n H_{r e n c}
$$

di mana: $\varphi_{r}=$ sudut gesek antara geotextile dan permukaan material tanah, $T_{g t}=$ gaya tarik material lembaran geotextile, $H_{\text {renc }}=$ tinggi rencana embankment.

Perkuatan dengan geotextile diletakkan di atas susunan balok gapit yang telah diperkuat oleh cerucuk (lihat Gambar 2), di mana dalam studi kasus ini adalah tiang-tiang kayu galam dipasang dengan jarak $(s) 1 \mathrm{~m}$ (atau $s$ 10D). Sehingga kapasitas dukung batas pemasangan tiang-tiang kayu dengan jarak $s>3 D$ dapat dihitung dengan persamaan statis:

$$
q_{c g}=\alpha \times c_{u}
$$

Koefisien friksi cerucuk metode statis $(\alpha)$ (Velde, E van der, 1996):

$$
\alpha=\left(0,5 \times \frac{L}{D}\right)^{-0,2} \times\left(\frac{c_{u}}{p_{0}^{\prime}}\right)^{-0,3}
$$

Rasio $\left(c_{u} / p^{\prime}{ }_{0}\right)$, kohesi tanah tak terdrainase rata-rata sepanjang tiang $\left(c_{u}\right)$ terhadap tekanan tanah efektif $\left(p^{\prime}{ }_{0}\right)$ disarankan Skempton's dalam (Suyuti et al., 2020a):

$$
\frac{c_{u}}{p_{0}^{\prime}}=0,11+0,0037 \times I P
$$

di mana $c_{u}=$ kohesi tanah sepanjang tiang, $L=$ panjang tiang, $D=$ diamater tiang, $I P=$ Indeks Plastisitas tanah dasar lunak (satuan \%).

Berat volume tanah setelah dipancangkan cerucuk. Maka, kondisi tanah dasar lunak di bawah embankment yang diperkuat cerucuk $\gamma_{s p}^{\prime}$ adalah dapat ditentukan (Gambar 3).

$$
\begin{aligned}
& \gamma_{s p}^{\prime}=\left[1-n_{p}\left(\frac{\pi D^{2}}{4 s^{2}}\right)\right] \gamma_{s 1}^{\prime}+n_{p}\left(\frac{\pi D^{2}}{4}\right) \gamma_{p} \\
& \gamma_{s 1}^{\prime}=\gamma_{s 1}-\gamma_{w}
\end{aligned}
$$

di mana: $n_{p}=$ jumlah cerucuk dalam 1 meter persegi, $\gamma_{s l}^{\prime}=$ berat volume tanah dasar sepanjang cerucuk, $\gamma_{p}=$ berat volume tiang kayu, $D=$ diameter tiang kayu, $\gamma_{s l}^{\prime}=$ berat volume air yang terperangkap tanah.

\subsection{Menentukan tinggi kritis embankment}

Untuk menentukan tinggi kritis embankment diperkuat geotextile $\left(H_{c r}\right)$, formula empiris dalam geoteknik dapat ditulis:

$$
H_{c r}=\frac{q_{n r 2}}{F k \gamma_{b}}
$$

di mana $F k=$ faktor keamanan, $\gamma_{b}=$ berat volume tanah timbunan embankment.

Dimensi dan parameter desain konstruksi embankment di atas tanah lunak diperkuat geotextile dan cerucuk adalah ditentukan pada Gambar 4. 


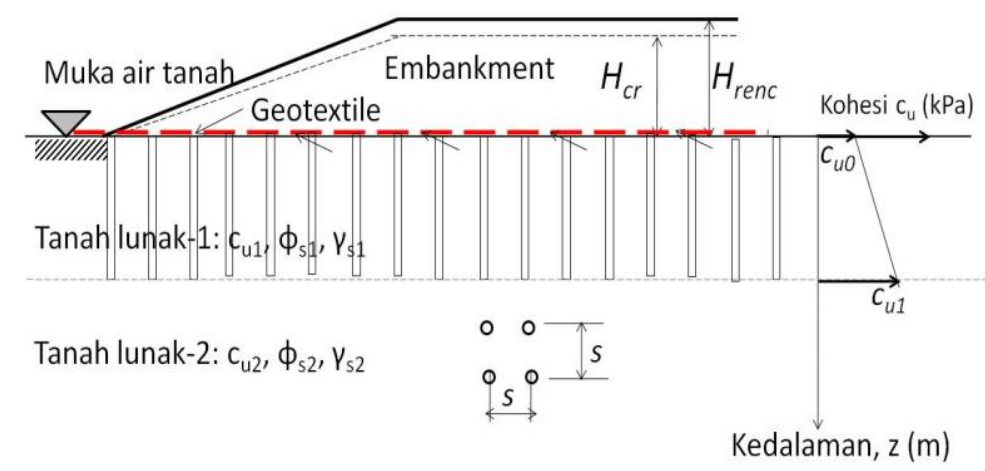

Gambar 4 Konstruksi setengah-embankment di atas tanah lunak diperkuat geotextile dan pondasi cerucuk

Kohesi rerata tanah dasar adalah dihitung dengan persamaan:

$$
c_{u}=\left(c_{u 0}+c_{u 1}\right) / 2
$$

dimana $c_{u 0}=$ kohesi pada permukaan tanah dasar, $c_{u l}=$ kohesi pada pemasangan cerucuk.

\section{Hasil dan Pembahasan}

Konstruksi timbunan pelebaran jalan di atas tanah lunak di Simpang Serapat KM 17 Lingkar Utara (Adriani and Herliyana, 2012), dimensi dan parameter tanah embankment jalan seperti lebar atas $\left(B_{0}\right) 9,5 \mathrm{~m}$, lereng $(n)$ 1,5, tinggi $\left(H_{\text {renc }}\right) 1,5 \mathrm{~m}$, berat $\left(\gamma_{b}\right) 20 \mathrm{kN} / \mathrm{m}^{3}$. Lebar bawah embankment tanah adalah diperoleh $\left(B_{1}\right) 14 \mathrm{~m}$.

Dimensi dan parameter sistem perkuatan dengan geotextile tarik $T_{g t}=55$ $\mathrm{kN} / \mathrm{m}$ (Sandyutama et al., 2015). Pemancangan tiang-tiang kayu galam klas IIA dengan diameter $(D)=10 \mathrm{~cm}$, jarak antara tiang $(s)=1 \mathrm{~m}$, dan panjang $(L)=4 \mathrm{~m}$. Parameter tanah dasar lempung seperti kohesi tak terdrainase rata-rata $\left(c_{u}\right)=18$ $\mathrm{kN} / \mathrm{m}^{2}$, berat volume $\left(\gamma_{s}\right)=14,6 \mathrm{kN} / \mathrm{m}^{3}$, sudut gesek tanah rerata diasumsikan $\left(\varphi_{s}\right)$ $\approx 0^{\circ}$ yang kedalamannya $(\mathrm{z})=25 \mathrm{~m}$ seperti pada Gambar 4 .

Dalam rangka simulasi perhitungan tinggi kritis embankment $\left(H_{c r}\right)$, maka perlu digunakan beberapa variasi Indeks Plastisitas tanah dasar $(I P)$ seperti $I P \leq 7 \%$ (rendah), IP = $7 \sim 17 \%$ (sedang), dan IP $\geq 27 \%$ (tinggi).

Simulasi perhitungan tinggi krtitis embankment jalan adalah dibuat beberapa variasi parameter dan dimensi perkuatan.

1) Kohesi tanah dasar lunak $\left(c_{u}\right)$ yang digunakan yang digunakan dalam simulasi sebagaimana dalam Tabel 1 berikut.

Tabel 1 Digunakan parameter kohesi tanah dasar lunak

\begin{tabular}{clll}
\hline Parameter & $\begin{array}{c}\text { (Pekerjaan } \\
\text { Umum, 2002) }\end{array}$ & $\begin{array}{c}\text { Nilai } \\
\text { interpretasi }\end{array}$ & $\begin{array}{c}\text { (Adriani and } \\
\text { Herliyana, 2012) }\end{array}$ \\
\hline Kohesi $c_{u 0}\left(\mathrm{kN} / \mathrm{m}^{2}\right)$ & 5 & 8 & 10 \\
\hline Kohesi $c_{u l}\left(\mathrm{kN} / \mathrm{m}^{2}\right)$ & 10 & 15 & 25 \\
\hline Rerata $c_{u}\left(\mathrm{kN} / \mathrm{m}^{2}\right)$ & 7,5 & 11,5 & 17,5 \\
\hline
\end{tabular}


2) Kapasitas dukung batas tanah dasar yang diperkuat geotextile dan cerucuk dengan variasi jarak antara tiang $s$, serta menngunakan nilai indeks plastisitas $I P=$ 7\%. Hasilnya dapat dilihat pada Gambar 5.

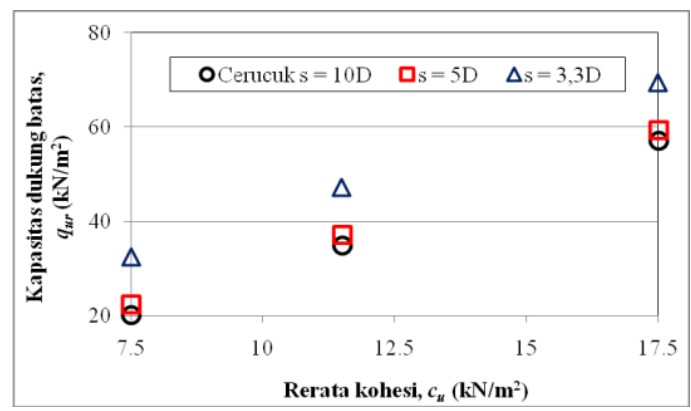

Gambar 5 Kapasitas dukung batas tanah dasar $\left(q_{u r}\right)$ dengan variasi kohesi $c_{u}$

$$
(I P=7 \%)
$$

Gambar 5 menunjukkan bahwa tanah dasar diperkuat dengan cerucuk berjarak $s=$ 3,3D adalah memberikan peningkatan signifikan kapasitas dukung batas $\left(q_{u r}\right)$ terhadap setiap variasi kohesi tanah $c_{u}$.

3) Perkuatan tiang dengan jarak $s=3,3 D, 5 D$ dan $10 D$, rerata kohesi tanah dasar $c_{u}=7,5 \mathrm{kN} / \mathrm{m}^{2}$, dan minimum faktor kapasitas dukung $N_{c}=3,7$ (Koerner dkk, 1987), $N_{c}=5,14$ (Das, 1979). Hasil simulasi perhitungan ditunjukkan pada Gambar 6, 7 dan 8.

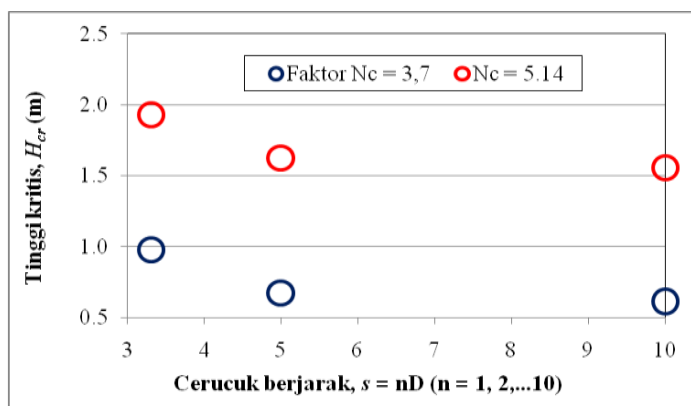

Gambar 6 Tinggi kritis embankment $\left(H_{c r}\right)$ dengan tanah nilai $I P=7 \%$

Gambar 6 menunjukkan bahwa dengan menggunakan nilai $F k=1,50$ untuk jalan klas II, telah diperoleh peningkatan tinggi kritis embankment $\left(H_{c r}\right)$ dengan $I P=7 \%, c_{u}=11,5 \mathrm{kN} / \mathrm{m}^{2}$ dan cerucuk berjarak $s=10 D$ adalah sebesar $H_{c r}=1,06$ $\mathrm{m}\left(\mathrm{N}_{\mathrm{c}}=3,7\right)$, dan $1,56 \mathrm{~m}\left(N_{c}=5,14\right)$.

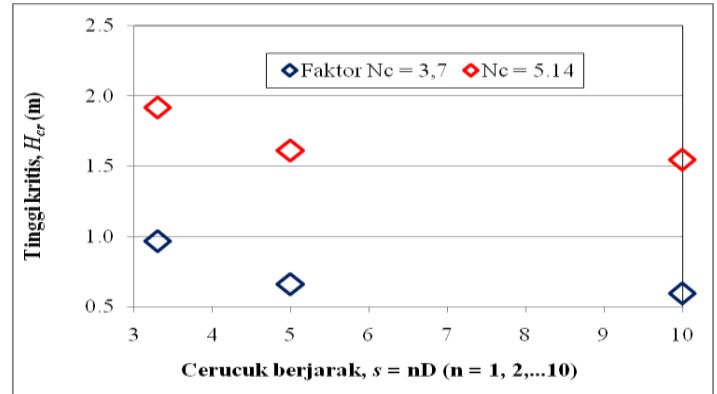

Gambar 7 Tinggi kritis embankment $\left(H_{c r}\right)$ dengan tanah nilai $I P=17 \%$ 
Gambar 7 dan 8 menunjukkan bahwa hasil simulasi perhitungan tinggi kritis embankment $\left(H_{c r}\right)$ dengan nilai $I P=17 \% \sim 27 \%, c_{u}=17,5 \mathrm{kN} / \mathrm{m}^{2}$ dan sebesar $H_{c r}$ $=1,7 \mathrm{~m}\left(N_{c}=3,7\right.$ dan dengan cerucuk berjarak $\left.s=10 D\right)$, dan 2,07 $\mathrm{m}\left(N_{c}=3,7\right.$ dan cerucuk berjarak $s=3,3 D$ ). Hasil simulasi perhitungan yang diperoleh adalah lebih besar tinggi rencana embankment $H_{\text {renc }}=1,50 \mathrm{~m}$. Namun hasil tersebut adalah belum memperhitungkan tekanan beban akibat beban kendaraan di atas permukaan perkerasan jalan, serta pengecekan terhadap syarat penurunan embankment.

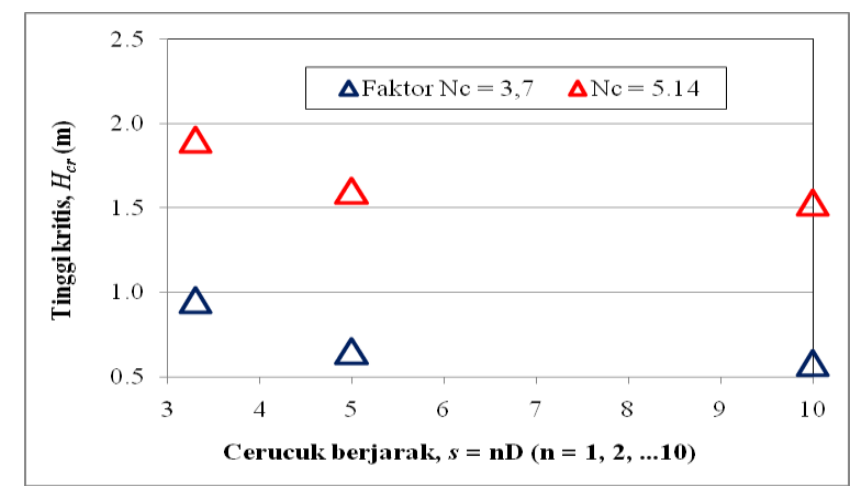

Gambar 8 Tinggi kritis embankment $\left(H_{c r}\right)$ dengan tanah nilai $I P=27 \%$

4) Faktor keamanan $F k=1,3,1,4$ (Pekerjaan Umum, 2002), dan $F k=1,5$ (Pekerjaan Umum, 2005), rerata Indeks Plastisitas $I P=17 \%$ dan kohesi sangat lunak $c_{u}=7,5 \mathrm{kN} / \mathrm{m}^{2}$. Hasil simulasi adalah ditunjukkan pada Gambar 9 .

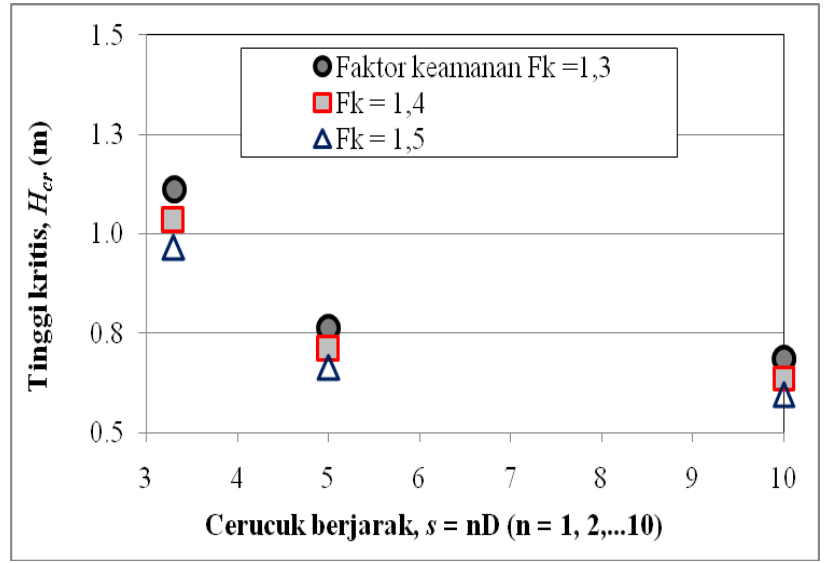

Gambar 9 Tinggi kritis embankment $\left(H_{c r}\right)$ terhadap faktor keamanan $(F k)$

Gambar 9 menunjukkan bahwa hasil simulasi perhitungan tinggi kritis embankment $\left(H_{c r}\right)$ adalah lebih 1,25 m untuk $F k=1,3$, dan sementara $H_{c r}$ kurang 1,03 m untuk $F k=1,4$ dan 1,5. Selanjutnya, tinggi kritis embankment adalah diperoleh signifikan pada cerucuk berjarak $s=3,3 D$. Sementara untuk tinggi kritis embankment $H_{c r}$ adalah diperoleh kurang jarak tiang $s=10 D$ dan $s=5,5 D$.

(1) Stabilitas embankment diukur dengan faktor keamanan $F k=1,5$, kohesi tanah dasar $c_{u}=7,5 \sim 17,5 \mathrm{kN} / \mathrm{m}^{2}$ (Lihat Table 1). Hasil simulasi ditunjukkan pada Gambar 10. 


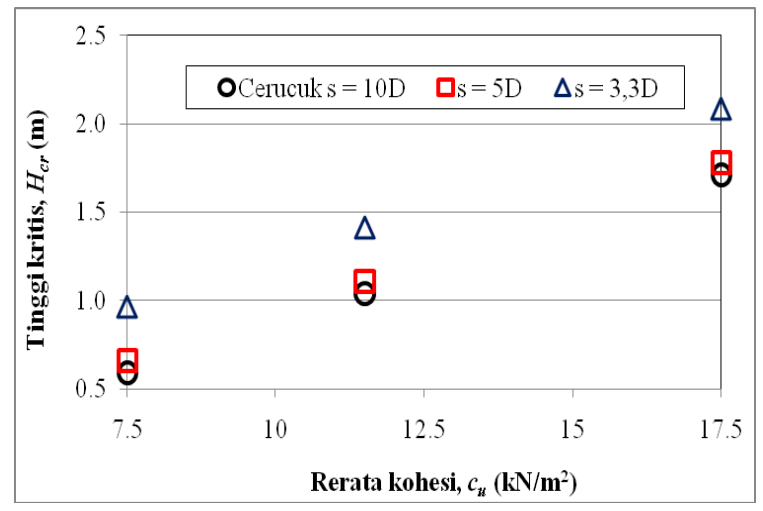

Gambar 10 Tinggi kritis embankment $\left(H_{c r}\right)$ terhadap rerata kohesi tanah lunak $c_{u}$.

Gambar 10 menunjukkan bahwa hasil simulasi perhitungan tinggi kritis embankment $H_{c r}$ terhadap variasi rerata kohesi tanah dasar $c_{u}$ dan $F k=1,5$, adalah diperoleh peningkatan linier terhadap pertambahan konsistensi tanahnya. Namun tinggi embankment kritis adalah diperoleh peningkatan signifikan untuk cerucuk berjarak $s=3,3 D$.

\section{Kesimpulan dan Saran}

\subsection{Kesimpulan}

Embankment di atas tanah sangat lunak $\left(c_{u}=11,5 \mathrm{kN} / \mathrm{m}^{2}\right)$ diperkuat geotextile dan cerucuk kayu diameter $\mathrm{D}=10 \mathrm{~cm}$, panjang $\mathrm{L}=4 \mathrm{~m}$, dan jarak antara tiang $\mathrm{s}=100 \mathrm{~cm}(\mathrm{~s}=10 \mathrm{D})$ adalah diperoleh desain embankment (kritis) $H_{c r}$ sebesar 1,06 m untuk $F k=1,5$ dan faktor kapasitas $\mathrm{N}_{\mathrm{c}}=5.14$. Hal ini hasilnya adalah lebih kecil dari data tinggi rencana $H_{\text {renc }}$ sebesar $1,50 \mathrm{~m}$. Sementara untuk embankment di atas tanah sangat lunak dengan $c_{u}=17,5 \mathrm{kN} / \mathrm{m}^{2}$, diperoleh desain embankment (kritis) $H_{c r}$ sebesar $1,7 \mathrm{~m}$, hal lebih besar dari data desain $H_{\text {renc }}$ sebesar $1,50 \mathrm{~m}$, namun jika faktor kapasitas dukung $N_{c}=3,7$ sebagaimana disarankan oleh (Koerner et al., 1987) adalah memberikan nilai lebih dekat terhadap rencana embankment $H_{\text {renc }}$ sebesar $1,5 \mathrm{~m}$. Di sisi lain, nilai indeks plastisitas tanah $(I P)$ tidak memberikan pengaruh signifikan terhadap kapasitas dukung tanah dengan tiang-tiang friksi kayu. Selanjutnya, metode penelitian adalah dapat digunakan sebagai cara praktis untuk mendesain tinggi embankment. Namun engineer masih perlu melakukan evaluasi juga terhadap penurunan embankment sebagai salah persyaratan konstruksi.

\subsection{Saran}

Simulasi perhitungan tinggi kritis embankment $H_{c r}$ di atas adalah menggunakan parameter kapasitas dukung batas tanah dasar dengan beberapa perkuatan. Karena itu, penulis menyarankan perlu adanya penelitian stabilitas pengaruh pengaku/ cap konvensional kayu atau bambu terhadap gaya perlawanan tarik untuk metode perhitungan keruntuhan guling keseluruhan embankment di atas tanah lunak. 


\section{Ucapan Terima Kasih}

Ucapan terima kasih disampaikan kepada Lembaga Penelitian dan Pengabdian Masyarakata LPPM, Universitas Khairun atas penyediaan dana penelitian skema PKUPT-Fakultas Teknik Tahun 2020. Terima juga kepada Laboratorium Mekanika Tanah-Teknik Sipil, Fakultas Teknik, Universitas Khairun yang telah menyediakan fasilitas untuk pelaksanaan penelitian ini.

\section{Daftar Kepustakaan}

Adriani, Herliyana, L., 2012. Analisa Timbunan Pelebaran Jalan Simpang Serapat KM-17 Lingkar Utara 11.

Braja, M.D., 1979. Introduction to soil mechanics, in: Introduction to Soil Mechanics. Iowa State University Press; 1st edition (1979), pp. 229-253.

Koerner, R.M., Hwu, B.-L., Wayne, M.H., 1987. Soft Soil Stabilization Designs Using Geosynthetics. Geotextiles and Geomembranes.

Pekerjaan Umum, 1999. Pedoman Teknik tata Cara Pelaksanaan Pondasi Cerucuk di Atas Tanah Lembek dan Tanah Gambut. PT. Mediatama Saptakarya ( PT. Medisa ).

Pekerjaan Umum, D., 2005. Stabilisasi Dangkal Tanah Lunak Untuk Konstruksi Timbunan Jalan (dengan Semen dan Cerucuk).

Pekerjaan Umum, D., 2002. Desain dan Konstruksi. Timbunan Jalan pada Tanah Lunak. PT. Virama Karya.

Sandyutama, Y., Samang, L., Imran, A.M., Harianto, T., 2015. Full Scale Model Test of Consolidation Acceleration on Soft Soil deposition with Combination of Timber Pile and PVD (Hybrid Pile). Int. J. Innov. Res. Adv. Eng. 2, 6 .

Suyuti, Jamalun, T., M. Darwis, 2018. Prediksi Stabilitas Pondasi Cerucuk Tradisional pada Bangunan Bertingkat di Atas Tanah yang Sangat Lunak 8.

Suyuti, Kazuhide, S., Atsushi, Y., 2020a. Stability Research of River Embankment on Soft Ground Using Traditional Reinfocement System, in: Stability Research of River Embankment on Soft Ground Using Traditional Reinfocement System. Gifu University, Jepang, Engineering A, pp. 1-120.

Suyuti, M. Rizal, S., Y. Damayanti, T., 2020b. Prediksi CBR-Lapangan Pada Pondasi Matras di Atas Tanah Lunak Diperkuat Tiang-Tiang Menggunakan Formula Klasik Terzaghi 10, 12.

Terzaghi, K., Peck, R.B., 2009. Soil Mechanics in Engineering Practice, in: Soil Mechanics in Engineering Practice. JOHN WILEY \& SONS, pp. 137-199.

Velde, E van der, K., H.J., 1996. A reliable method to determine friction capacity of piles driven into clays. 1996-12-31 337-346.

Yamanouchi, T., Gotoh, K., 1979. A Proposed Practical Formula of Bearing Capacity for Earthwork Method on Soft Clay Ground Using a Resinous Mesh. Kyusu Univ. 52, 201-207.

Yudiawati, Y., Marzuki, A., 2008. Pondasi Dangkal diatas Tanah Lunak dengan Perkuatan Cerucuk Galam Berdasarkan Percobaan Lapangan 6. 